\title{
The Effect of Using Cost Policy in Improving the Pricing Efficiency in Food Industrial Sector
}

\section{Hamdan MW*}

Department of Accounting, Faculty of Finance and Administration, University of Philadelphia, Jordan

\begin{abstract}
The cost system of enterprise is considered very crucial in determining the pricing of good in enterprises. The objective of this paper is to investigate the effect of using the cost as a tool to determine the final price of products. To accomplish the objectives of this research questionnaire was used as a tool to collect data. Four items were included: the effective costs, control of costs, providing data for planning and support management decisions and its effect price effectiveness. Comprehensive survey was used to collect data. The results showed that the cost policy can be used as a tool to determine competitive prices.
\end{abstract}

Keywords: Cost; Price; Competiveness

\section{Introduction}

The high competiveness among companies in food sector makes the prices a good determinant of market share as the price is considered one of the important components of the marketing mix. The good prices determine the extent of sales and the cash flow of the company. These factors will determine the ability of company to develop its products as well as to make balance between productivity and returns [1]. Local markets affected directly by the exports competiveness. The prices of local prices goods will determine the ability of these goods to compete the exported ones [2].

The strategic cost management considered one of the modern applications that depend mainly on analyzing the cost and using its information to draw and execute strategies. The enterprise manages its sources and activities that uses those sources through the concentration on events and conditions that direct these activates. So, the cost management concerns with all activities related to planning and controlling the cost to use different sources economically taking into consideration the interests and preferences of customers [3]. In this aspect, the determination of all processes considered crucial in industrial company to find out those with high cost to minimize the cost with the reservation of the quality of the final product.

Cost management provides the top management of information about the percentage of use of sources per product. To accomplish that effective measurement tools should be used to reach comprehensiveness [4]. Cost management passes through three stages according to the context and as a response to changes [5]. First stage represents the stage of recording all information to prepare reports and estimate the production cost. This stage is very important in reserving cost and keeping quality. The second stage concentrates on sharing the benefit information to prepare the financial reports. The third stage concentrates on cost management through the high concern of the current expenses to help in decision making to reduce the costs. The different cost activities can be collected to form the strategic cost management as a part of product management in the enterprise.

Correct and effective use of strategic cost management becomes very crucial in the enterprise as the response to the age environmental changes increase including the glob competiveness, technological development, care of customer, developing the managerial systems, and political, social and economic considerations [6]. Shank and Govindarajan reported that strategic cost management concentrates on managing operations, activities, performance and customer satisfactions, choosing the proper cost compared to competitors, determining the tools to support the excellence of the enterprise [7]. Finally, the strategic cost management will be used to measure the extent of achieving the strategic goals, supporting the competiveness experience, and the care of performance efficiency through financial indicators. Different criteria should be available to reach effective strategic cost management including the flexible cost management and continuous change, using strategic analysis to evaluate the extent of executing strategies using financial ratios, well understanding of activities, cost and income.

Goods pricing affected by different factors including the cost, competitors, and demand [7]. The cost can be used to manage on the short or long run [8]. Cardinaels et al. studied the effect of additional costs and indirect costs on goods prices [9]. It was reported that the income and prices are highly affected by the cost related to the type of product quality. The precision of the cost reports will affect directly the effectiveness of pricing. Deo and Penkar studied the effect of structure of cost on the pricing in large enterprises [10]. They found that the enterprise control the prices which covers the constant cost. Buchheit indicated that the constant cost affect the pricing efficiency [11-15].

\section{Methodology}

Companies competiveness affected by different factors including prices and quality. The study objective is to figure out the effect of using costing policy on improving the financial ratios, increasing returns, opening new markets, and increasing market share. To accomplish the objectives, questionnaire was prepared composed of three parts. The first part was concerned to collect demographic and experience information about accountant in the food companies, while the second part concerned with collecting data about the effective cost

*Corresponding author: Mohammad W Hamdan, Department of Accounting Faculty of Finance and Administration, University of Philadelphia, Jordan, Tel: 00962795558875; E-mail: hamdan.papers@gmail.com

Received May 02, 2018; Accepted July 17, 2018; Published July 25, 2018

Citation: Hamdan MW (2018) The Effect of Using Cost Policy in Improving the Pricing Efficiency in Food Industrial Sector. Int J Account Res 6: 175 doi:10.35248/2472-114X.18.6.175

Copyright: ( 2018 Hamdan MW. This is an open-access article distributed unde the terms of the Creative Commons Attribution License, which permits unrestricted use, distribution, and reproduction in any medium, provided the original author and source are credited. 
Citation: Hamdan MW (2018) The Effect of Using Cost Policy in Improving the Pricing Efficiency in Food Industrial Sector. Int J Account Res 6: 175 doi: $10.35248 / 2472-114 X \cdot 18 \cdot 6.175$

Page 2 of 5

of products, controlling costs, providing information for planning, and using cost to draw policies and decision making. The third part of the questionnaire concerned with collecting information about the market share, opening new markets, increase returns, and improving the competiveness. Lickert's five scale used ranging from highly agree (5) to high disagree (1). Comprehensive survey conducted for the food industrial companies. Table 1 shows the distribution of respondents.

Reliability of the collected questionnaire was tested using Cronbach's alpha. The results of reliability varied from very good to excellent, which indicates that the questionnaire is reliable to be used for analysis (Table 2).

\section{Results}

\section{Increase market share}

Table 3 shows that effective pricing contributes in product preference based on price (3.91), also the results showed that effective pricing facilitate the circulation of product in the market (3.69). Moreover, effective pricing increase the demand on the product in the market (3.67), increase the sales and reflects the product quality (3.29).

\begin{tabular}{|c|c|}
\hline Sample components & Number of questionnaires \\
\hline Accountant & 46 \\
\hline Financial manager & 15 \\
\hline Managerial & 15 \\
\hline Total & 76 \\
\hline
\end{tabular}

Table 1: Sample Structure.

\begin{tabular}{|c|c|}
\hline Variables & Cronbach's' Alpha \\
\hline Cost policy & 0.932 \\
\hline Effective cost of product & 0.815 \\
\hline Cost observation & 0.803 \\
\hline Providing data for planning & 0.840 \\
\hline Using cost to draw policies & 0.856 \\
\hline Pricing Efficiency & 0.944 \\
\hline Improve market share & 0.849 \\
\hline Open new markets & 0.822 \\
\hline Increase returns & 0.789 \\
\hline Increase competiveness & 0.888 \\
\hline
\end{tabular}

Table 2: Cronbach's' Alpha of reliability analysis.

\section{Open new markets}

Results show that the effective pricing would affect the opening of new markets (3.65). The results also showed that the effective pricing facilitate the reach of new markets (3.98), increase competiveness in the new markets (3.78), contribute in creating harmonization between the products and its distribution (3.62), increase the exports of the product (3.53), and determining the targeted markets (3.33). These results even it has positive effect but still this effect varied according to targets needed (Table 4).

\section{Increase the returns}

The results showed that price efficiency will increase the returns (3.65) through increasing the sales (3.91), improve the opportunity to market more than one product at the same time (3.87), decrease the cost (3.87), increase profits (3.65), and increase the offers introduced by the company (3.49) (Table 5).

\section{Increase competiveness}

Effective pricing increase the competiveness of the product (4.07). The highest contribution to competiveness through the improve of the quality (4.31), followed by the higher care given for the major activities to improve the quality (4.11), and showing the product quality (4.06). Lower agreement was given for the increase of attractiveness to the products (3.87). The results showed that the pricing play effective role in improving the competiveness of the products (Table 6).

\section{Attitudes to use the cost as a tool for pricing}

Determination of effective cost to improve price efficiency: The general attitude for the effect of determining the effect cost to improve price efficiency was moderate (3.6). The highest agreement was for considering the competitors prices when determining the product cost (3.8) and the study of cost is considered in determining the products costs (3.8). Less agreement was given for the effect of the determination of the original cost of product on improving pricing efficiency (3.7) and the search for alternatives for inputs to decrease the cost (3.7) (Table 7).

The least agreement was given for the consideration of cost of other products to determine the cost of one product (3.6) and studying the cost of production stage to decrease the cost and improve pricing efficiency (3.5). The last agreement was for the effect of the cost studies for the indirect cost to improve the efficiency (3.2).

\section{Item}

Increase market share

Effective pricing facilitate the selection of products as alternative based on price

Effective pricing facilitate circulation of product in markets

Effective pricing increase the demand on product

Effective pricing increase the sales

Effective pricing reflects the products quality

\begin{tabular}{|c|c|}
\hline Mean & Std. Dev \\
\hline 3.64 & 0.89 \\
\hline 3.91 & 0.62 \\
\hline 3.69 & 1.06 \\
\hline 3.67 & 0.99 \\
\hline 3.64 & 0.91 \\
\hline 3.29 & 1.14 \\
\hline
\end{tabular}

Table 3: Means and standard deviation of the effect of effective pricing.

\begin{tabular}{|l|c|c|}
\hline Item & Mean & Std. Dev \\
\hline Open new market & 0.81 & 3.65 \\
\hline Pricing efficiency facilitates the reach of new markets & 3.98 \\
\hline Pricing efficiency increase competiveness in the new markets & 3.78 \\
\hline Price efficiency facilitates the distribution of the enterprise products & 3.62 \\
\hline Price efficiency facilitates the export of the products & 3.53 \\
\hline Pricing efficiency helps in determining the targeted markets & 1.09 \\
\hline
\end{tabular}

Table 4: Means and standard deviation of the effect of pricing on opening new markets. 
Citation: Hamdan MW (2018) The Effect of Using Cost Policy in Improving the Pricing Efficiency in Food Industrial Sector. Int J Account Res 6: 175 doi: 10.35248/2472-114X.18.6.175

Page 3 of 5

\section{Item}

\section{Increase the returns}

Price efficiency increase the sales

Price efficiency improve the opportunity to market different products per once

Pricing efficiency decreases the cost and increase the profits

Effective pricing increases the offers introduced by the enterprise

Price efficiency increase the profit margin

Table 5: Effect of price efficiency on increasing the returns.

\section{Item}

Increase competiveness

Effective cost estimation improve the quality of the product and competiveness

Pricing according to activity increase the care for the major activities that increase the competiveness

Effective pricing reflects the product quality

Pricing according to activity increase the quality and competiveness

Effective pricing increase the attractiveness to the product

\begin{tabular}{|c|c|}
\hline Mean & Std. Dev \\
\hline $\mathbf{3 . 6 5}$ & $\mathbf{0 . 7 1}$ \\
\hline 3.91 & 0.62 \\
\hline 3.87 & 0.60 \\
\hline 3.65 & 0.79 \\
\hline 3.49 & 0.72 \\
\hline
\end{tabular}

Table 6: Effect of price efficiency on competiveness.

\section{Item}

Effective cost to improve price efficiency

The enterprise take into consideration the competitors prices when determining the product cost

The final price is determined through detailed study of the costs

Original cost estimation increase pricing efficiency

Search for alternatives to decrease the cost

Take into consideration the cost of other products in determining the cost of the product

Studying the cost of production stages decrease the costs and improve pricing efficiency

\begin{tabular}{|c|c|}
\hline Mean & Std. Dev \\
\hline 4.07 & 0.541 \\
\hline 4.31 & 0.77 \\
\hline 4.11 & 0.88 \\
\hline 4.06 & 0.93 \\
\hline 3.98 & 0.84 \\
\hline 3.87 & 0.69 \\
\hline
\end{tabular}

Cost studies decrease the indirect cost and improve pricing efficiency

\begin{tabular}{|c|c|}
\hline Mean & Std. Dev \\
\hline 3.6 & 0.9 \\
\hline 3.8 & 0.9 \\
\hline 3.8 & 1.1 \\
\hline 3.7 & 1.3 \\
\hline 3.7 & 1.2 \\
\hline 3.6 & 1.2 \\
\hline 3.5 & 1.2 \\
\hline 3.2 & 1.2 \\
\hline
\end{tabular}

Table 7: Attitudes for the effect of determination of effective cost on improving price efficiency.

\section{Item}

Cost control to improve pricing efficiency

Follow up the cost to improve the pricing of products

Finding special division for cost management contributes in improve pricing

Designing systems to supervise the cost of different products

Assigning staff to study the cost compared to competitors

Adjusting cost according to market research

Studying the competitors cases to price products and increase competences

Executing studies for the effectiveness of prices

\begin{tabular}{|c|c|}
\hline Mean & Std. Dev \\
\hline 3.7 & $\mathbf{0 . 8}$ \\
\hline 4.0 & 1.1 \\
\hline 3.9 & 1.1 \\
\hline 3.8 & 1.0 \\
\hline 3.6 & 1.2 \\
\hline 3.6 & 1.2 \\
\hline 3.3 & 1.1 \\
\hline 3.0 & 1.2 \\
\hline
\end{tabular}

Table 8: Trends for cost control to improve efficiency.

\section{Cost control to improve pricing efficiency}

The trend for cost control to improve pricing efficiency was moderate (3.7). The highest evaluation was for the follow up of the cost to improve the pricing of products (4.0). The trends started to decrease when the activities needs from the enterprise extra cost to find specialized divisions and systems to control the cost in the company. The trend decreased for finding a division care for cost management helping in improving the price index (3.9), also the trend dropped more for findings system inside the company helping in price control (3.8). The least trend recorded for executing studies that helps in improving the pricing effectiveness (3.0) (Table 8).

\section{Providing data required for planning}

Table 9 shows that the agreement of providing data for planning cost was moderate (3.8). The highest agreement was for providing data for the changes of cost to improve pricing with mean (4.1), followed by executing studies about cost effectiveness, modifying the cost based on final price, providing data about competitors concerning the cost with mean (3.9). The third order was for finding division for cost management and assigning the experts to manage the cost data (3.8).
The least and negative trend was for designing systems to control the cost (2.9). The lack of systems to control cost in companies indicates the extend of extra efforts to provide data to control the cost.

\section{Using cost data for planning and decision-making}

Table 10 shows the usage of data for planning and decisionmaking. The results showed that the trend for using data for planning and decision-making was moderate (3.04) and the positive moderate trend was recorded for using experts in cost management to improve pricing (3.5). The trend of using historical electronic records for costing and using records for production inputs and output was moderate. The trends of studying the price, cost and quality was negative (2.9), also the trend for studying the price reasonability was negative (2.8).

\section{The effect of cost management on prices efficiency}

The effect of cost policy on market share: The results showed that different parameters of using cost in pricing explain only $23 \%$ of the market share justification. The highest significant effect was for controlling cost to improve pricing, while the least effect was for using cost to draw policies to improve competiveness (Table 11). 


\section{Item}

Data provision for planning cost

Providing data for the changes of cost to improve pricing

Executing studies about cost effectiveness

Modifying the cost based on final price

Providing data about competitors concerning the cost

Finding division for cost management

Assigning experts to manage the cost data

Designing systems to control the cost

\begin{tabular}{|c|c|}
\hline Mean & Std. Dev \\
\hline 3.8 & $\mathbf{0 . 9}$ \\
\hline 4.1 & 1.1 \\
\hline 3.9 & 1.0 \\
\hline 3.9 & 1.0 \\
\hline 3.9 & 0.8 \\
\hline 3.8 & 1.1 \\
\hline 3.8 & 1.1 \\
\hline 2.9 & 1.3 \\
\hline
\end{tabular}

Table 9: Means and st. dev. for the trends of providing data required for planning

\section{Item}

Using cost for planning and decision making

Using experts in cost management to improve pricing

Using historical electronic records for cost

Using records for production inputs and outputs

Studying the price, cost and quality

Studies about price reasonability

\begin{tabular}{|c|c|}
\hline Mean & Std. Dev \\
\hline 3.04 & 1.1 \\
\hline 3.5 & 1.2 \\
\hline 3.0 & 1.3 \\
\hline 3.0 & 1.2 \\
\hline 2.9 & 1.1 \\
\hline 2.8 & 1.1 \\
\hline
\end{tabular}

Table 10: Means and st. dev. for using cost data for planning and decision making.

\begin{tabular}{|l|r|}
\hline Source of variation & t value \\
\hline Constant & 0.113 \\
\hline Determining the effective cost to improve pricing & 0.197 \\
\hline Controlling cost to improve pricing & 0.343 \\
\hline Providing data to minimize cost and improve pricing & 0.191 \\
\hline Using cost to draw policies to improve competiveness & 0.076 \\
\hline Aduj R-square & 0.23 \\
\hline Model probability & 0.001 \\
\hline
\end{tabular}

Table 11: The effect of cost policy on market share

\section{Source of variation}

Constant

Determining the effective cost to improve pricing

Controlling cost to improve pricing

Providing data to minimize cost and improve pricing

Using cost to draw policies to improve competiveness

Aduj R-square

Model probability

\begin{tabular}{|c|c|}
\hline$t$ value & Probability \\
\hline 0.113 & 0.056 \\
\hline 0.197 & 0.001 \\
\hline 0.343 & 0.001 \\
\hline 0.191 & 0.001 \\
\hline 0.076 & 0.139 \\
\hline 0.23 & \\
\hline 0.001 & \\
\hline
\end{tabular}

\section{The effect of cost policy on competiveness}

Cost policy explains $33.1 \%$ of company competiveness. The highest effect was for the determination of the effective cost to improve pricing, while the least effect was for using cost to draw policies to improve competiveness (Table 12).

\section{The effect of cost policy on maximizing returns}

The cost policy justified only $28.8 \%$ of return maximization. The highest effect was for the determination of effective cost to improve pricing, while the least effect was for using cost to draw policies to improve competiveness (Table 13).

\section{The effect of cost policy on opening new markets}

Cost policy explains $39.5 \%$ of opening new markets. The highest effect was for determining the effective cost to improve pricing, while the least effect was for using cost to draw policies to improve competiveness (Table 14).

\section{Discussion}

The results showed that cost policy usage to accomplish

\begin{tabular}{|c|c|}
\hline t value & Probability \\
\hline 0.115 & 0.101 \\
\hline 0.289 & 0.001 \\
\hline 0.247 & 0.001 \\
\hline 0.171 & 0.001 \\
\hline 0.015 & 0.739 \\
\hline 0.331 & \\
\hline 0.001 & \\
\hline
\end{tabular}

competiveness is high significant. This may resulted of considering of other food producing companies and reflect these prices to minimize the cost of product to improve competiveness. Moreover, the results showed the cost policies improve competiveness through defining the final price of products according to market studies and competitor's prices.

The food companies search for alternatives to minimize the cost of its products, which improve the pricing efficiency. The policy used in these companies depend on collecting information about the competitors prices to improve the cost to accomplish good profit bases on goods final price. The results showed that studying the cost of each production stage will help he companies to minimize the cost. The care of the companies to minimize the indirect cost is low. This is because the companies considered the indirect costs less important to improve the pricing of the products and they concentrate on the original cost that affect the pricing directly.

Food companies concern with the costs as a tool to improve the competiveness in the market. They do that through the concentration on follow up of the cost changes to improve the pricing. Furthermore, some companies concern with finding specialized division to 
Citation: Hamdan MW (2018) The Effect of Using Cost Policy in Improving the Pricing Efficiency in Food Industrial Sector. Int J Account Res 6: 175 doi: $10.35248 / 2472-114 X .18 .6 .175$

Page 5 of 5

\begin{tabular}{|l|c|}
\hline Source of variation & t value \\
\hline Constant & 0.249 \\
\hline Determining the effective cost to improve pricing & 0.304 \\
\hline Controlling cost to improve pricing & 0.273 \\
\hline Providing data to minimize cost and improve pricing & 0.114 \\
\hline Using cost to draw policies to improve competiveness & 0.001 \\
\hline Aduj R-square & 0.001 \\
\hline Model probability & 0.050 \\
\hline
\end{tabular}

Table 13: Linear regression for the effect of cost policy on maximizing returns.

\begin{tabular}{|l|c|}
\hline Source of variation & Probability \\
\hline Constant & 0.061 \\
\hline Determining the effective cost to improve pricing & 0.212 \\
\hline Controlling cost to improve pricing & 0.312 \\
\hline Providing data to minimize cost and improve pricing & 0.129 \\
\hline Using cost to draw policies to improve competiveness & 0.223 \\
\hline Aduj R-square & 0.002 \\
\hline Model probability & 0.001 \\
\hline
\end{tabular}

Table 14: Linear regression for the effect cost policy on opening new markets.

minimize cost and increase profitability. On the other hand, the care for competitors considered crucial tool to determine the prices and minimize the cost accordingly.

\section{Conclusions and Recommendations}

The objective of this research is to test the role of cost on improving the efficiency of pricing in food companies. To accomplish the objective of this research, the questionnaire used as a tool to collect data. The study targets the accountants and managerial staff in these companies. The results showed that the care of companies for market studies is not enough to use it as a tool to improve competiveness and improve pricing. The food companies should improve their care for creating databases for costs and pricing to improve the performance of the company. The case for establishing databases will improve the search for alternatives to minimize costs.

\section{References}

1. Assahin Mohammd, (2004) Marketing and Strategies. Dar Aljameya, Alesknderia, Egypt.

2. Rashid Ahmad (2001) Marketing strategy. Part 2. Dar Al Nuhda Alarabeya, Cairo.

3. Hansen D, Mowen M (2009) Cost Management: Accounting and Control. $5^{\text {th }}$ ed. South-Western, Gengage Learning. USA.

4. Shim JK, Siegel J (2009) Modern Cost Management and Analysis. $3^{\text {rd }}$ edn. Library of Congress, USA.
5. Kaplan S (2005) How to Win and Keep Big Customers. Library of Congress, USA.

6. Blocker CP, Flint DJ, Myers MB, Slater SF (2010) Proactive Customer Orientation and Its Role for Creating Customer Value in Global Markets. J Acad Mark Sci 39: 216-233.

7. Shank J, Govindarajan (2008) Strategic Cost Management. Amazon, USA.

8. Marn M, Baker W, Zawada C (2010) The Price Advantage. Wiley, USA.

9. Cardinaels E, Roodhooft F, Warlop L, Herck GV (2008) Competitive pricing in markets with different overhead costs: Concealment or leakage of cost information? J Account Research 46: 761-784.

10. Deo P, Penkar S (2008) BMI, INC: A case study in cost and pricing structure International Journal of Business Research 8: 125-133.

11. Buchheit S (2004) Fixed cost magnitude, fixed cost reporting format, and competitive pricing decisions: some experimental evidence. Contemporary Accounting Research 21: 1-24.

12. Blocher E, Stout D, Cokins G (2010) Cost Management: A Strategic Emphasis $4^{\text {th }}$ edn. Amazon, USA.

13. Hooman E, Maxwell S (2003) Perspectives in Behavioral Pricing. Journal of Business Research, 56: 401-403.

14. Saffi P, Sigurdsson K (2011) Price efficiency and short-selling. Review of Finance Studies 24: 821-852.

15. Sekaran U (2008) Research Methods For Business: A skill Building Approach New York: John Wiley and Sons. 